Insulin Content of Pancreas of Different Specres.

\begin{tabular}{|c|c|c|c|}
\hline \multirow[b]{2}{*}{ Species } & \multirow{2}{*}{$\begin{array}{l}\text { Weight of pancreas } \\
\text { (gm./100 gm. } \\
\text { body weight) }\end{array}$} & \multicolumn{2}{|c|}{ Insulin content of pancreas } \\
\hline & & $\begin{array}{l}\text { Units/gm. } \\
\text { pancreas }\end{array}$ & $\begin{array}{l}\text { Units } / 100 \mathrm{gm} \text {. } \\
\text { body weight }\end{array}$ \\
\hline Chimpanzee & $0 \cdot 09$ & $11 \cdot 2$ & 1.01 \\
\hline Dog & 0.23 & $3 \cdot 3$ & $0 \cdot 76$ \\
\hline Cat & $0 \cdot 21$ & $2 \cdot 2^{4}$ & $0.47^{4}$ \\
\hline Rabbit & $\begin{array}{l}0 \cdot 15 \\
0 \cdot 13\end{array}$ & $\begin{array}{l}9 \cdot 5 \\
7 \cdot 8^{5}\end{array}$ & $\begin{array}{l}1 \cdot 12 \\
1 \cdot 17^{5}\end{array}$ \\
\hline Guinea pig & $\begin{array}{l}0.37 \\
0.31\end{array}$ & $\begin{array}{l}0.08 \\
0.23^{5}\end{array}$ & $\begin{array}{l}0.028 \\
0.070^{5}\end{array}$ \\
\hline Rat & 0.48 & $1 \cdot 3$ & $0 \cdot 62$ \\
\hline Mouse & $1 \cdot 10$ & $1 \cdot 7$ & $1 \cdot 87$ \\
\hline
\end{tabular}

(Methods are those of Marks and Young (1939) unless otherwise indicated.)

are influenced by the blood sugar-level ${ }^{3}$ and appear to be associated with the insulin-secreting mechanism.

When insulin was dissolved in an extract of guinea pig pancreas, only about 50 per cent of the expected activity could be found in the biological assay (mouse test), although the apparent activity of the insulin was not reduced if an acid aqueous solution of insulin was injected into one side of the mouse while the extract of guinea pig pancreas was simultaneously injected into the other. Substances in the extract therefore appear to interfere with the absorption of insulin from the subcutaneous tissues; but it is improbable that such an effect could entirely account for the fact that guinea pig pancreas appears to contain only about $1 / 15$ the amount of insulin found in the pancreas of the rat.

Preliminary experiments have shown that the mouse resembles the rat in exhibiting a rise of pancreatic insulin content as the result of treatment with crude ox anterior pituitary extract, whereas the rabbit pancreas, like that of the dog, exhibits a fall in insulin content under similar conditions. With the rabbit, however, the fall was not so great as with the dog, a fact in keeping with the less consistent response of the rabbit to the diabetogenic action of a crude anterior lobe extracts.

H. P. Marks.

F. G. Young.

National Institute for Medical Research, London, N.W.3.

' Rest, C. H., Campbell, J., and Haist, R. E., J. Physiol., 97, 200 (1939).

${ }^{2}$ Marks, H. P., and Young, F. F., Chem. and Ind., 58, 6527(1939); Lancet, i, $493(1940)$.

${ }^{3}$ Woerner, C. A., Anat. Rec., 71, 33 (1938); 75, 91 (1939).

' cf. Scott, D. A., and Fisher, A. M., Amer. J. Physiol., 121, 253 (1938).

${ }^{5}$ Picrate insulin extraction method of Dodds, E. C., and Dickens, F., Brit. J. Exp. Path, 5, 115 (1924).

- Young, F. F., Biochem. J., 32, 513 (1938).

\section{Concentrated Plasma in Histamine Shock}

Best and Solandt ${ }^{1}$ recently reported that the intravenous injection of pituitrin and concentrated serum produces beneficial effects on blood-pressure in dogs suffering from traumatic shock or histamine poisoning. We have studied the effects of various fluids in thirty cats injected with $5 \mathrm{mgm}$. of histamine per $\mathrm{kgm}$., which in control experiments produces death within two hours. Animals receiving intravenously 10-25 c.c. per $\mathrm{kgm}$. of concentrated plasma (concentrated to one half or one third its original volume) within ten minutes of the histamine injection survived for more than four hours and the blood pressure usually recovered to about normal level. Intra-

venous saline was ineffective. Normal plasma or gum. saline were also less satisfactory, generally producing only a short-lived rise of blood pressure. The administration of concentrated plasma may thus be of value in patients suffering from severe traumatic shock or other conditions associated with markedly increased capillary permeability.

C. A. KEELE.

Department of Physiology,

H. H. Kwiatkowski.

Middlesex Hospital Medical School, London, W.1. May 24.

1 Best, C. H., and Solandt, D. Y., Brit. Med. J., i, 799 (1940).

\title{
Prevention of Seedling Blight in the Flax Crop
}

SemduIng blight, caused by Colletotrichum lini (Westerd.) Toch., is a disease of flax which is likely to assume greater importance should the cultivation of flax and the home-saving of seed become more widely and intensively practised. The parasite is seed-borne and damage caused by it to the crop would be largely prevented if a satisfactory method of seed disinfection, whereby the parasite is killed and the germination of the seed unimpaired, could be found.

In view of the possibility of seed-borne diseases of flax becoming of greater import, the problem of their prevention has occupied the attention of the Plant Disease Division of the Northern Ireland Ministry of Agriculture for the past two years. During this time rapid and accurate technique has been evolved for the examination of flax seed samples for seed-borne parasites, and a sorting test has been devised for the rapid discrimination between likely and unlikely seed dress. ings applied for the purpose of parasite extermination.

During the summer of 1939 a large number of chemical dressings were examined by the sorting test for the purpose of determining their efficiency, and among a range of materials submitted by the Imperial Chemical Industries, Ltd., an experimental product styled R.D. 7846 and containing tetramethylthiuram disulphide as its active constituent gave very promising results. One very pleasing feature of this product is that it is apparently non-poisonous. It is in the form of a finely divided powder and gave satisfactory results when applied to the seed at the rate of $3 \mathrm{gm}$. per $500 \mathrm{gm}$. (approximately $5 \mathrm{oz}$. per bushel of $54-56 \mathrm{lb}$.).

More extensive trials with the use of this material have been planned for 1940 , and from preliminary results in the field which have already been obtained, the promise shown by the laboratory tests has been upheld. So far no phytocidal effects have been observed in the crops and the attack of seedling blight has been reduced to negligible proportions.

This statement should be regarded as of a preliminary nature and it merely records the possibility of $R . D .7846$ being a suitable flax seed dressing for the prevention of seedling blight. It is not suggested that this fungicide is the most suitable for the prevention of other or all seed-borne diseases of flax, but owing to the possibility of the growing importance of seedling blight it is felt that this observation merits serious attention, especially at the present time.

Ministry of Agriculture,

Plant Disease Division,

Queen's University,

Belfast. May 23.
A. E. Muskett.

J. Colmoun. 